\title{
Risk Management Study for the Retired Hanford Site Facilities Risk Evaluation Work Procedure for the Retired Hanford Site Facilities
}

Prepared for the U.S. Department of Energy Office of Environmental Restoration and Waste Management

\section{(W) Westinghouse \\ Hanford Company Richland, Washington}

Hanford Operations and Engineering Contractor for the

U.S. Department of Energy under Contract DE-AC06-87RL10930

Approved for Public Release 
WHC-EP-0619

Volume 2

UC-630

\title{
Risk Management Study for the Retired Hanford Site Facilities
}

Risk Evaluation Work Procedure for the Retired Hanford Site Facilities

\author{
G. A. Coles \\ M. V. Shultz \\ W. E. Taylor
}

Date Published

April 1993

Prepared for the U.S. Department of Energy Office of Environmental Restoration and Waste Management

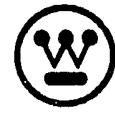

Westinghouse

Hanford Company Richland, Washington 99352

Hanford Operations and Engineering Contractor for the

U.S. Department of Energy under Contract DE-AC06-87RL10930 


\section{LEGAL DISCLAIMER}

This report was prepared as an account of work sponsored by an agency of the United States Government. Neither the United States Government nor any agency thereof, nor any of their employees, nor any of their contractors, subconiractors or their employees, makes any warranty, express or implied, or assumes any legal liability or responsibility for the accuracy, completeness, or any third party's use or the results of such use of any information, apparatus, product, or process disclosed, or represents that its use would not infringe privately owned rights. Reterence herein to any specific commercial product, process, or service by trade name, trademark, manufacturer, or otherwise, does not necessarily constitute or imply its endorsement, recommendation, or favoring by the United States Government or any agency thereof or its contractors or subcontractors. The views and opinions of authors expressed herein do not necessarily state or reflect those of the United States Government or any agency thereof.

This report has been reproduced from the best available copy. Available in paper copy and microfiche.

Available to the U.S. Department of Energy and its contractors from

Office of Scientific and Technical Information

P.O. Box 62

Oak Ridge, TN 37831

(615) $576-840$

Available to the public from the U.S. Department of Commerce National Technical Information Service

5285 Port Royal Road

Springfield, VA 22161

(703) $487-4650$

Prinled in the Uniled States of Amorica

DISCLM-1.CHP $(1.91\}$ 


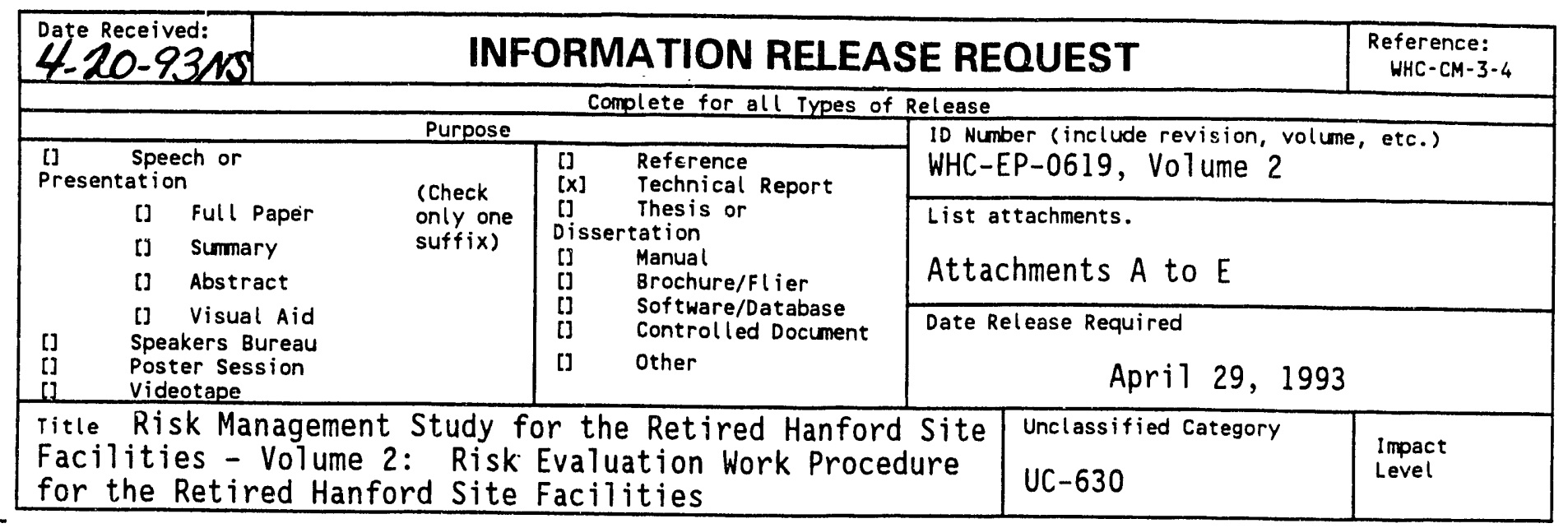

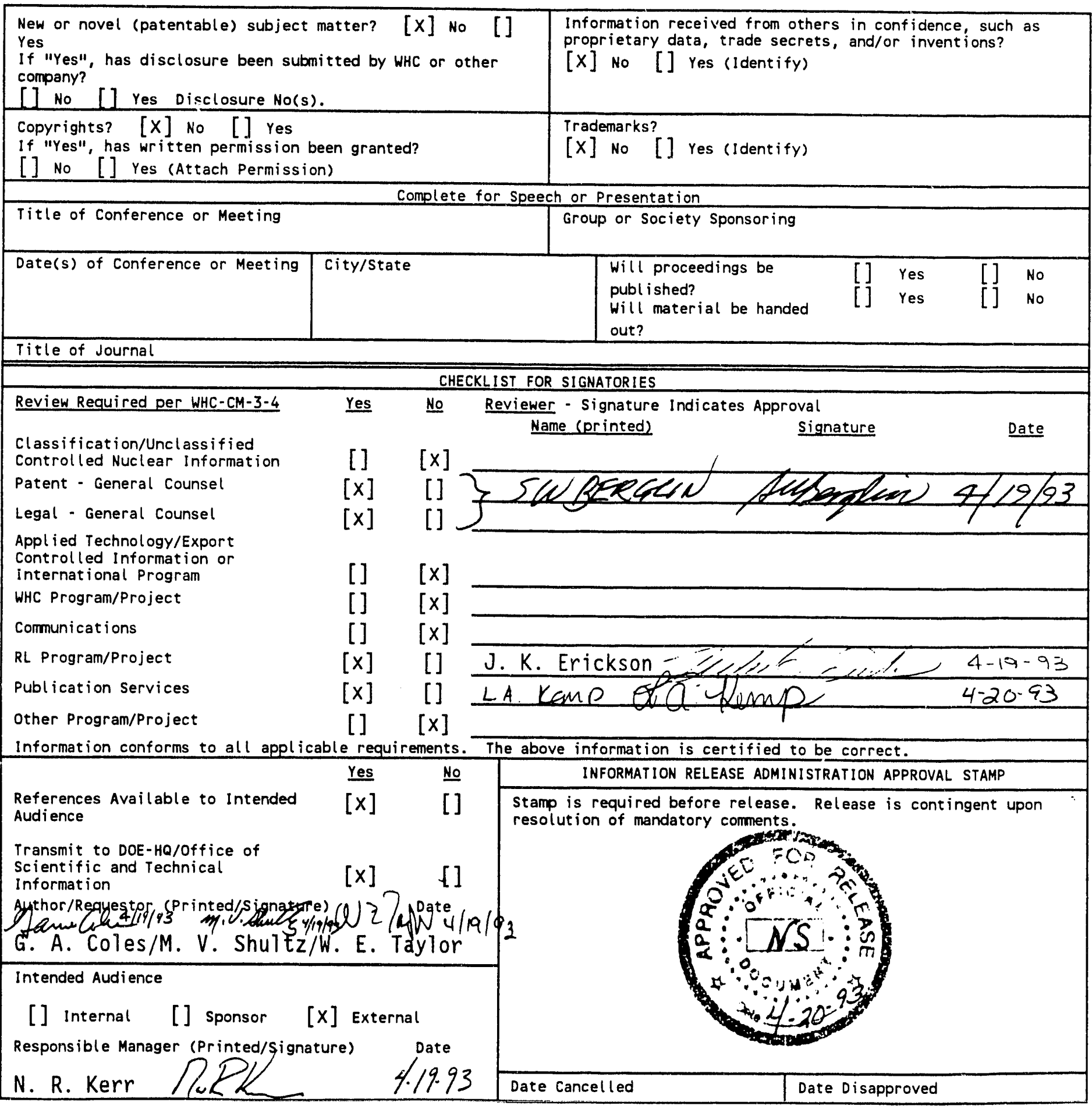


WHC-EP-0619, VOLUME 2

ID Number

Lead Author

Phone

G. A. Coles/M. V. Shultz/W. E.

Taylor

Project or Program

Environmental Restoration

Editor

J. D. Hylton/H. E. Marquez

Mandatory Comments conly mandatory coments are

to be documented. All other corments should be

made on a copy of the information submitted for

review and returned to the author.)

6-1731 H4-67

Lead Org Code 29550

Phone 1 MSIN

6-6937 H4-67

Reviewer Name Date

\& Signature

Date

\begin{tabular}{|l|l}
\hline Resolution &
\end{tabular}

Sponsor Agency (DOE, DOT, NRC, USGS, etc.)

West inghouse Hanford Company

DOE/HQ Program (DP, EH, EM, NE, etc.)

EM

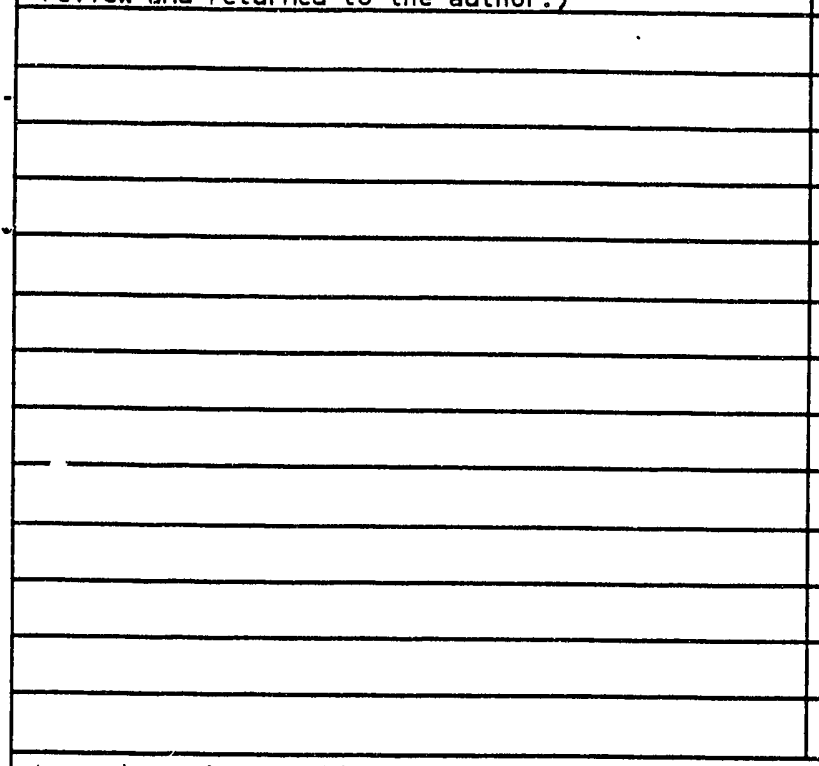

Legends/Wotices/Markings (required per WHC-CM-3-4 or guidance organization.) (Reviewer initials)

\begin{tabular}{lcc} 
& \multicolumn{2}{c}{ Affix } \\
Applied Technology & $\frac{\text { Yes }}{\text { No }}$ \\
Business-Sensitive Information & {[]} & {[]} \\
Computer Software Notice & {[]} & {[]} \\
Copyright License Notice & {[]} & {[]} \\
Export Controlled Information & {[]} & {[]} \\
Legal Disclaimer & {[]} & {[]} \\
Limited Disclosure & {[]} & {[]} \\
Patent Status & {[]} & {[]}
\end{tabular}

Predecisional Information

Programmatic Notice

Proprietary Information

Purpose and Use

[ ] [ ]

Thes is/Dissertation

[ ] [ ]

Trademark Disclaimer

[ ] [?

[ ] [ ]

Unclassified Controlled Nuclear

Information/Official Use Only

[ ] [ ]

Additional Information 
WHC-EP-0619

VOLUME 2

APPROVAL PAGE

DOCUMENT TITLE: RISK EVALUATION WORK PROCEDURE FOR THE RETIRED SURPLUS HANFORD SITE FACILITIES

Prepared by:
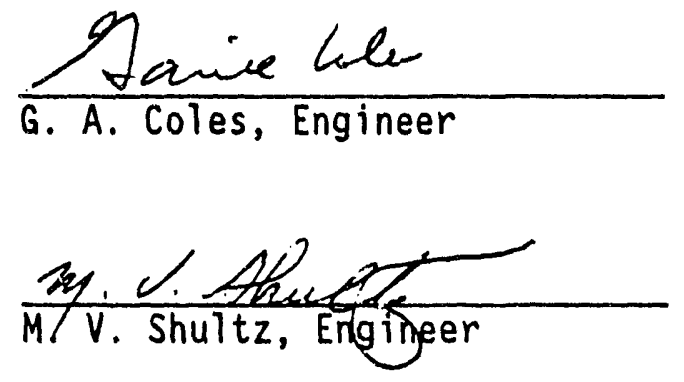

Approved by:
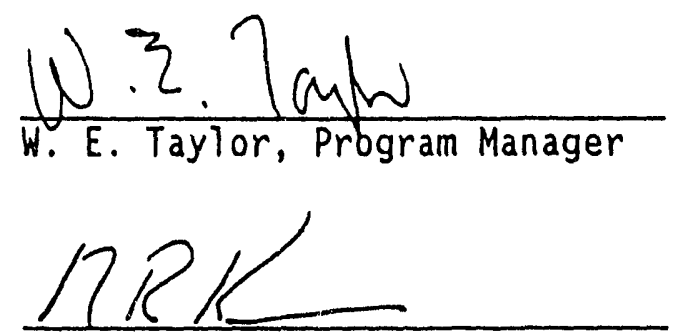

N. R. Kerr, Manager,

Environmental Restoration Safety Support

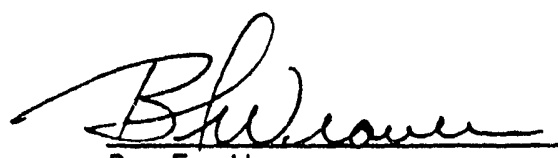

B. F. Weaver,

Inactive Facilities Surveillance and Maintenance

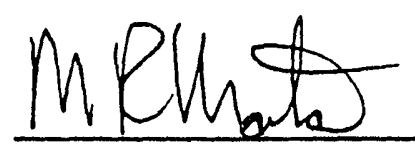

M. R. Morton, Manager, Decommissioning Support

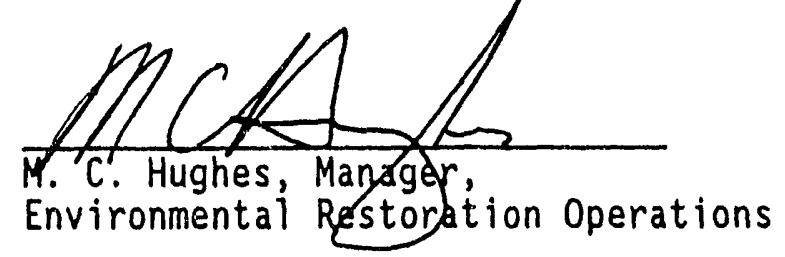

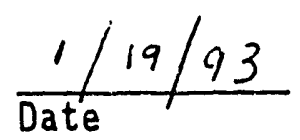
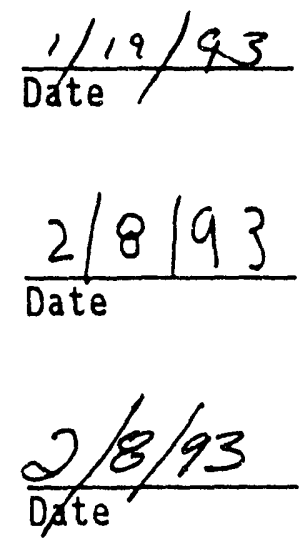

$\frac{2-8-93}{\text { Date }}$
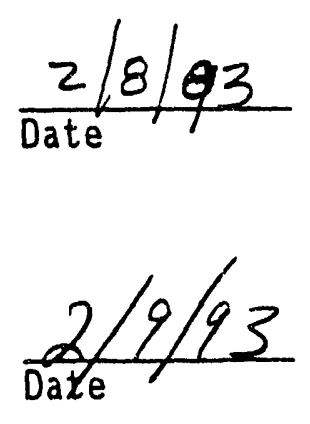
RISK EVALUATION WORK PROCEDURE FOR THE RETIRED SURPLUS HANFORD SITE FACILITIES

G. A. Coles

M. V. Shultz

W. E. Taylor

\section{ABSTRACT}

Risk from retired surplus facilities has always been assumed to be low at the Hanford Site as the facilities are inactive and have few potentials for causing an off site hazardous material release. However, the fatal accident that occurred in the spring of 1992 in which an employee fell through a deteriorated roof at the 105-F Reactor Building has raised the possibility that retired facilities represent a greater risk than was originally assumed. Therefore, Westinghouse Hanford Company and the U.S. Department of Energy management have determined that facility risk management strategies and programmatic plans should be reevaluated to assure risks are identified and appropriate corrective action plans are developed. To evaluate risk management strategies, accurate risk information about the current and projected condition of the facilities must be developed. This work procedure has been created to address the development of accurate and timely risk information. By using the evaluation results in this procedure, it will be possible to create a prioritized baseline for managing facility risk until all retired surplus facilities are demolished. 
WHC-EP-0619

VOLUME 2

This page intentionally left blank. 


\section{CONTENTS}

1.0 INTRODUCTION AND PURPOSE ...................... 1

1.1 SCOPE . . . . . . . . . . . . . . . . 1

1.1.1 Risk Evaluation Work Procedure . . . . . . . . . . . . 1

1.1.2 Risk Evaluation . . . . . . . . . . . . . . . 1

2.0 WORK PROCEDURE .......................... 2

2.1 RISK EVALUATION PROCEDURE ................ 8

2.1.1 Responsibilities ................... 8

2.1.2 Requirements.................. 9

2.2 PROCEDURE . . . . . . . . . . . . . . . . . . . 9

2.2.1 Facility Hazard Investigation ........... . 10

2.2.2 Facility Hazard Risk Evaluation . . . . . . . . . . . 10

2.2.3 Assessment of Results . . . . . . . . . . . . 11

3.0 REFERENCES ......................... 12

\section{FIGURES}

1 Basis Development .................... 4

2 Building Investigation ................. 5

3 Building Hazard Risk Evaluation . . . . . . . . . . . . . . 6

4 Determine Building Risk .. . . . . . . . . . . . . . 7

\section{APPENDIXES}

A FINDINGS REPORT . . . . . . . . . . . . . . . . . . . A-1

B FINDINGS EVALUATION WORKSHEET . . . . . . . . . . . . . B-1

c CONSEqUENCE CATEGORIES ................... c

D LIKELIHOOD INDEX . . . . . . . . . . . . . . . . . . . . . D-1

E RISK MATRIX . . . . . . . . . . . . . . . . . . . E-1 
WHC-EP-0619

VOLUME 2

This page intentionally left blank. 
RISK EVALUATION WORK PROCEDURE FOR THE RETIRED SURPLUS HANFORD SITE FACILITIES

\subsection{INTRODUCTION AND PURPOSE}

This work procedure provides a plan to obtain qualitative information that characterizes certain risks associated with the retired surplus facilities on the Hanford Site. Information obtained will specifically characterize risk contributors that threaten human health and safety or create potential environmental release issues. This procedure involves identification of hazards and evaluations of their risks. The resulting risk information will provide (1) insights on dominant risk contributors and sensitivities, and identification of areas that may need more detailed study; (2) a way of comparing the risks among facilities both in the present and future; and ultimately (3) a basis for carry-on activities related to improved management decision making and loss prevention.

\subsection{SCOPE}

This section provides the scope of the risk evaluation work procedure and the evaluation itself.

\subsubsection{Risk Evaluation Work Procedure}

The scope of this risk evaluation work procedure is as follows:

- Development of risk evaluation structure and criteria

- Definitions of responsibilities and interdisciplinary relationships

- Development of procedures for evaluating risk

- Definitions of documentation requirements and formats.

Determination of the specific facilities to be evaluated or the evaluation schedule is not within the scope of this document.

\subsubsection{Risk Evaluation}

The criteria for a risk evaluation procedure for retired facilities are provided in a plan outlined in correspondence (Hughes 1992) from Westinghouse Hanford Company (WHC) to the U. S. Department of Energy, Richland Field Office (RL). This plan is an integrated response to the large number of findings, recommendations, and proposed actions that followed reviews of the fatality that occurred at the 105-F Reactor Building in 1992. The key recommendations from that plan that are related to this procedure are listed here: 
- Evaluations should be made using information collected during walkdown investigations of the retired facilities

- Walkdown investigations should be performed by competent safety professionals

- Desired outcome is a measurement of the risk to humans and the environment from each retired facility

- Evaluations should use the Priority Planning Grid (PPG) approach

- Risks should be categorized by near-term (immediate to five years) and long-term (beyond five years).

This evaluation uses elements of the PPG approach. Accordingly, it uses the concepts of relative risk and numerical indices to provide a qualitative estimate of risk. This approach requires only order-of-magnitude estimates of the frequency and consequences of events.

The estimates will be made by competent safety professionals who will investigate each retired facility. A forecast of risk 5 to 10 years into the future will be estimated for each hazard. This evaluation will identify the high risk facilities and their dominant risk contributors.

This evaluation includes only risks to human safety and the environment. It treats occupational and public risk on a similar basis. Some hazardous material releases represent a double threat; exposure to an individual and risk to the environment. Both risks are accounted for in this evaluation as contributing to overall risk. This evaluation does not include quantification of latent cancer effects for onsite or offsite releases of hazardous materials. Risk related to releases to the environment is estimated based on simple size and material considerations rather than regulatory/statutory limits.

\subsection{WORK PROCEDURE}

This procedure outlines a risk-based evaluation of the deactivated retired facilities at the Hanford Site. Worksheets, reporting formats, consequence and likelihood tables, and associated technical bases are provided as appendices. These appendices are called out as needed by steps in the procedure.

This procedure incorporates elements of the WHC PPG method discussed in WHC-CM-1-3, Management Requirements and Procedures (MRP 5.1). The PPG was developed as a result of direction given in correspondence from RL to WHC to implement certain comprehensive self-assessment programs (Wagoner 1991). However, because of the specific requirements of this work, significant changes from the system described in WHC-CM-1-3 are necessary.

The purpose of a PPG is to rank order a list of findings for corrective action. The PPG assigns relative risk values as a way to prioritize findings so resources can be allocated effectively. The PPG addresses many other concerns such as: public perception; investment protection; and violation of 
WHC-EP-0619

VOLUME 2

Federal and State laws. In this procedure, the relative risk values associated with a retired facility are added to produce a total risk index, and also focuses on risks to human safety and potential unplanned environmental effects. In this procedure, the investigators performing the walkdowns also participate in the risk evaluation process. The risks of some hazards will be projected into the future (5 to 10 years). These are the key differences between the risk evaluation outlined here and the application of the PPG described in WHC-CM-1-3.

An evaluation using a PPG approach is not a probabilistic assessment with precisely defined errors bands; rather, it is an elicitation of expert judgement about the likelihood and consequences of some identified hazard. In this procedure, expert judgement will be augmented by professional investigations of the retired facilities.

One of the importance steps in this process is establishing the risk relationship among consequence categories. For example, how should death be weighed against severe injury or against an environmental release? Also, should offsite deaths be weighed differently than onsite deaths? These questions have an effect on the final risk estimates (as verified in Solomon et a1. 1989). With regard to the relationship between an onsite and an offsite death, no differentiation is made. This is in variance with the WHC $P P G$, but reflects the fact that retires facilities provide only risk and no benefit. However, the structure described in this procedure has the flexibility to allow for changes in these relationships with minimal effort.

In summary, this procedure consists of a series of steps iterated over each of the retired facilities. A flowchart of this procedure is shown in Figures 1, 2, 3, and 4. After the initial basis development (Figure 1), a team of investigators will examine the facilities according to their appropriate disciplines with the aid of hazard identification checklists (Figure 2). This process will generate a list of findings that will be evaluated in a method similar to the PPG application described in WHC-CM-1-3 (Figure 3 ). From the evaluation process the risk of each finding will be estimated, ultimately determining the risk posed by each retired facility. Also, from information obtained further risk characterization such as insights into dominant risk contributors and risk sensitivities is possible (Figure 4). This will provide a basis for carry-on work such as cost tenefit and risk management. 
WHC-EP-0619

VOLUME 2

Figure 1. Basis Development.
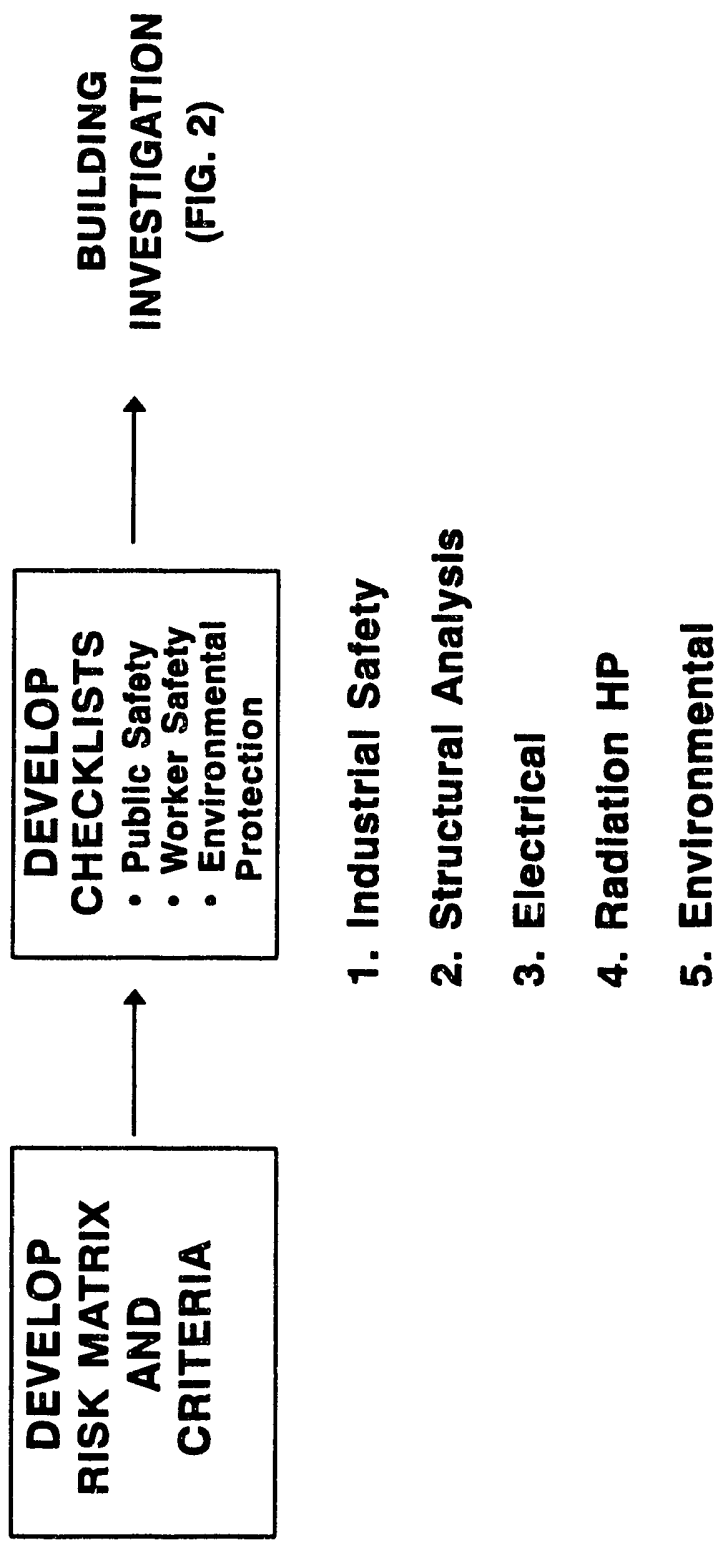
WHC-EP-0619

VOLUME 2

Figure 2. Building Investigation.

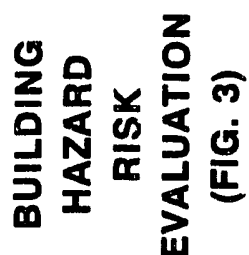
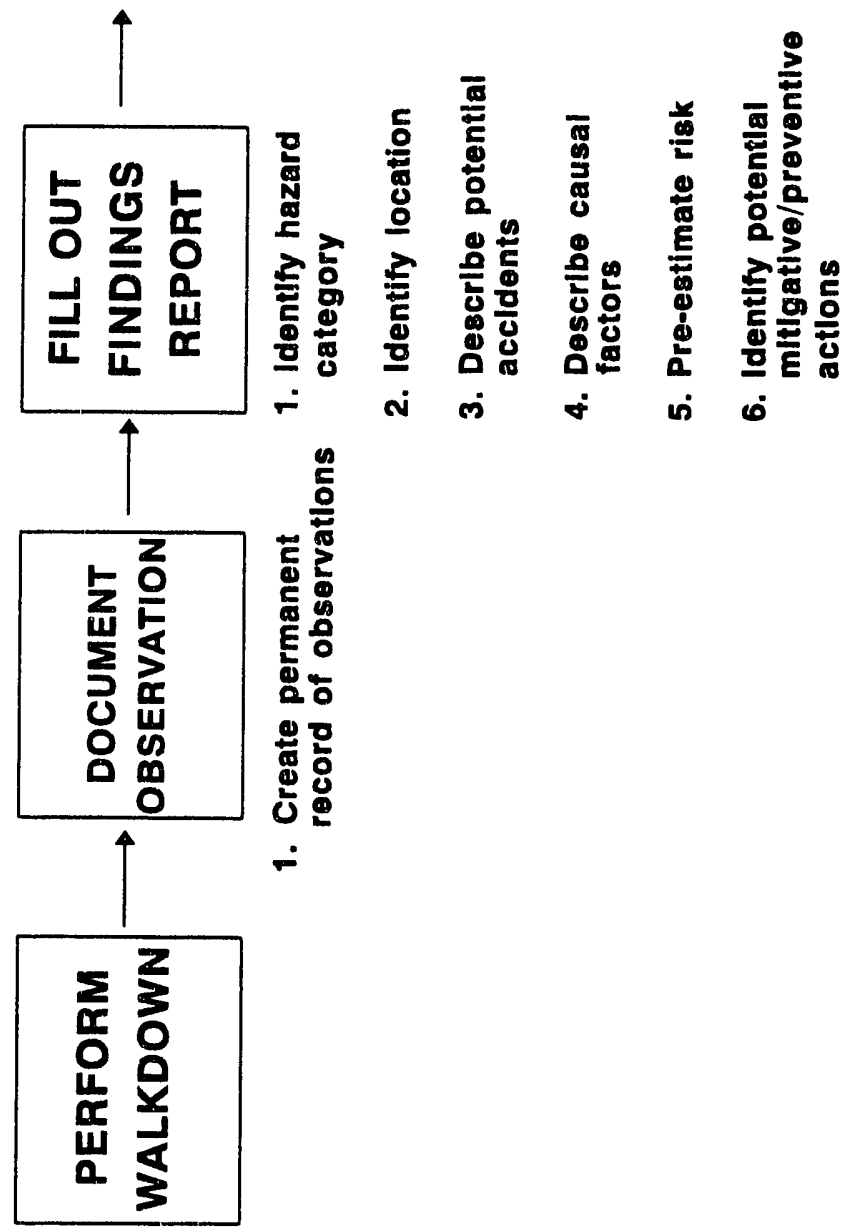
Figure 3. Building Hazard Risk Evaluation.

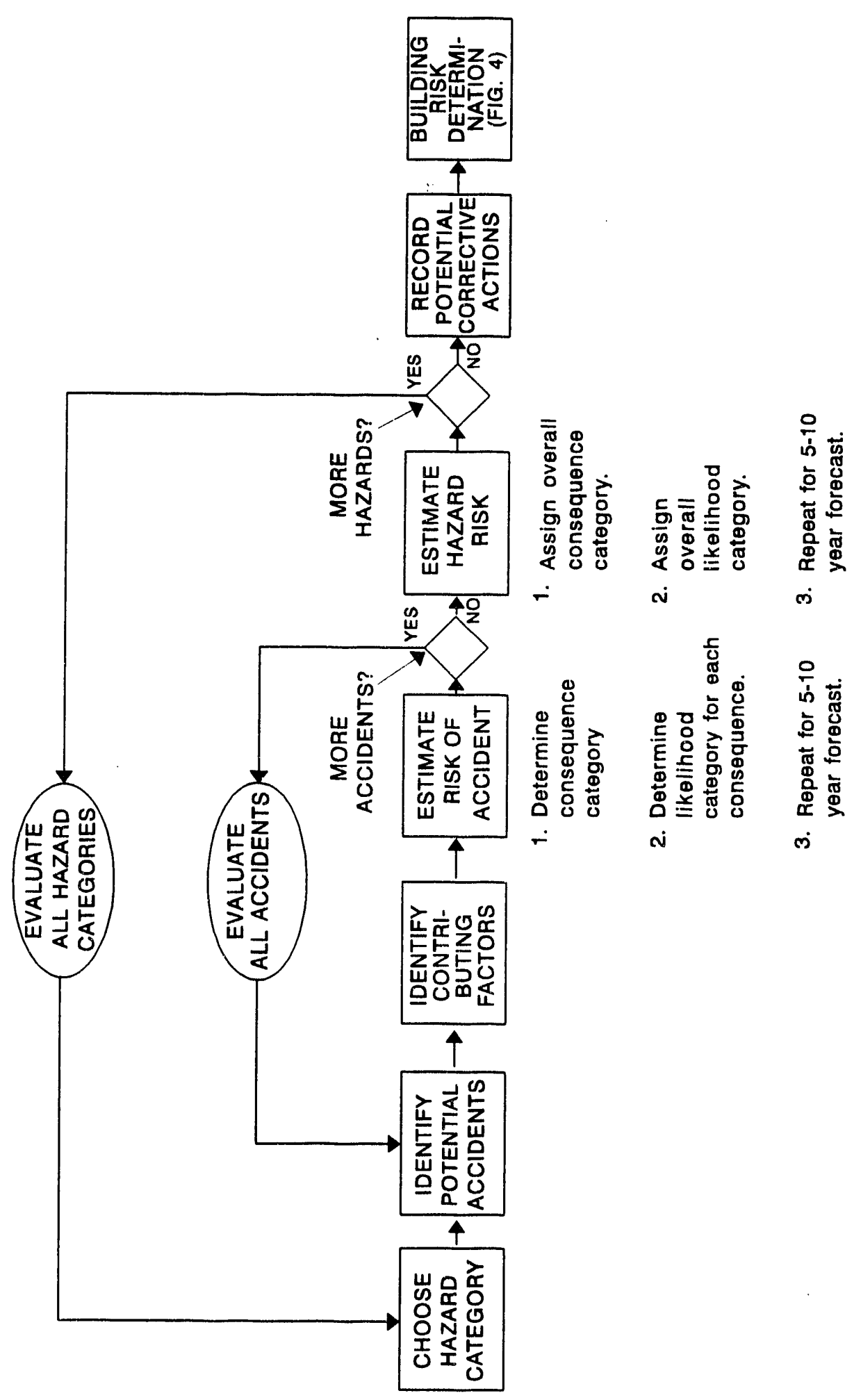


Figure 4. Determining Building Risk.

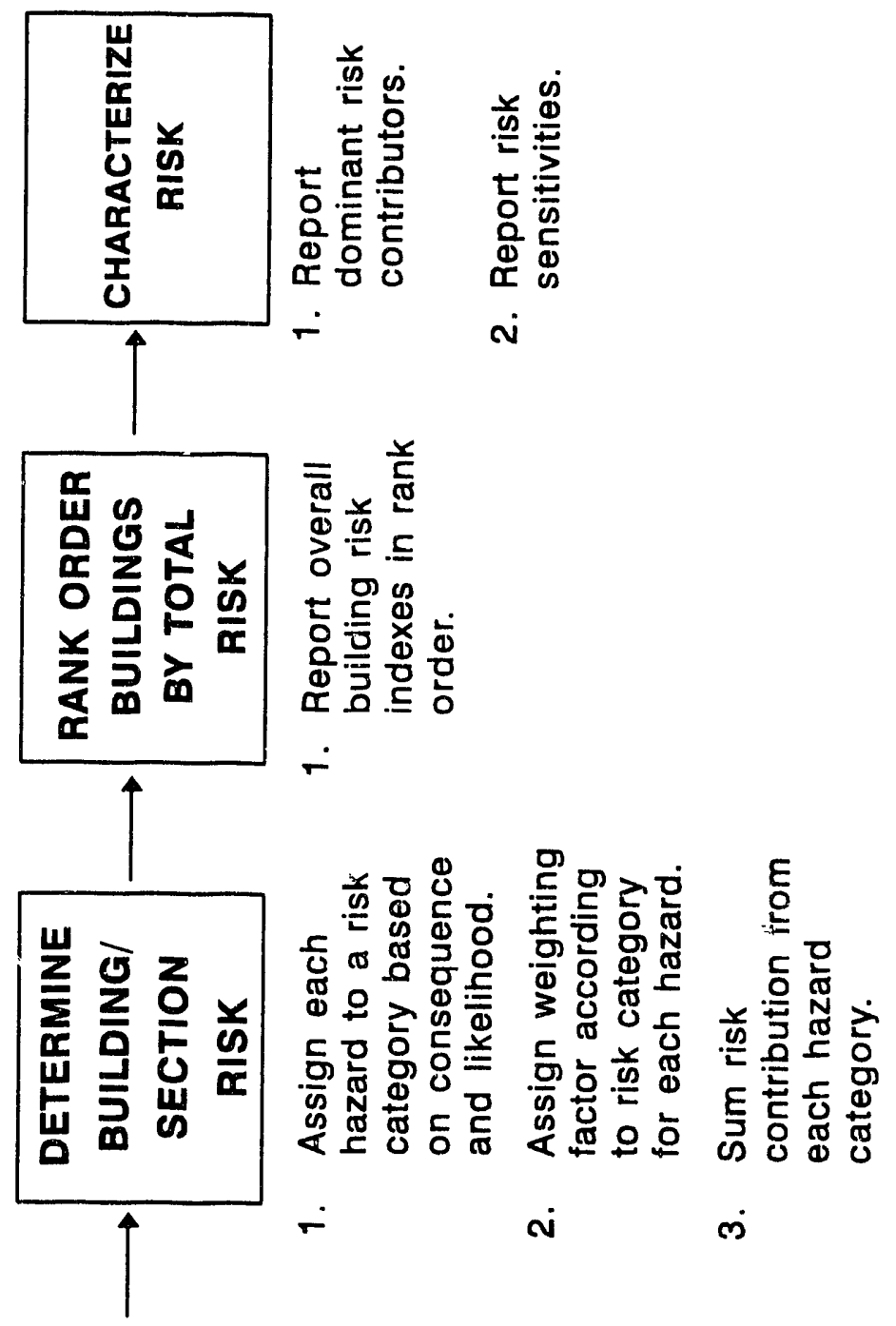




\subsection{RISK EVALUATION PROCEDURE}

This section describes the risk evaluation procedure that will be used to quantify the risks posed by the hazards associated with the retired facilities. The section also includes a description of the responsibilities and requirements for the responsible managers and team members.

\subsubsection{Responsibilities}

2.1.1.1 Program Manager. The program manager has the following responsibilities:

- Ensure overall program needs are provided such as staffing, scheduling, and other logistics.

- Ensure there are sufficient competent personnel trained in their appropriate professional disciplines to perform facility investigations for hazards and to estimate relative risk values.

- Ensure personnel are adequately briefed on known retired facility hazards and have proper safety and security training.

- Facilitate availability of supporting personnel such as building escorts or craft workers.

- Verify that team members comply with requirements related to personnel protective equipment and other entrance requirements.

- Prepare the final report.

2.1.1.2 Environmental Restoration Operation Manager. The Environmental Restoration Operation manager has the following responsibilities:

- Provide funding and necessary support personnel.

- Provide emergency response guidance upon the discovery of any imminent danger.

2.1.1.3 Team Risk Evaluation Lead. The Team Risk Evaluation Lead has the following responsibilities:

- Facilitate the risk evaluation process; document the risk evaluations; and report results to the Program Manager.

- Achieve a mutual understanding of the relative risk values among the risk evaluation team members.

- Collect, organize, and prepare for filing the raw and summarized data.

- Assist in the preparation of the final report. 
WHC-EP-0619

VOLUME 2

2.1.1.4 Risk Evaluation Team Members. The risk evaluation team members have the following responsibilities:

- Follow all facility entry requirements and report any imminent danger to the Program Manager.

- Perform the hazard investigation of the retired facilities within the time span allowed for entry.

- Participate in the team evaluation process to determine facility risk.

- Request or acquire specialty resources or personnel if needed.

- Prepare field data for the final report.

\subsubsection{Requirements}

- Retired facility hazard investigations and risk evaluations shall be performed by the team members.

- All members shall have completed facility orientation training before investigating each facility.

- Facility investigations and evaluations shall be performed by professionals trained in structural, electrical, industrial, radiation, and environmental safety disciplines.

- The Team Risk Evaluation Lead shall be a risk assessment analyst.

- The risk evaluation process shall follow this outlined procedure.

A final external publication report shall document all hazard findings, risk evaluations, and engineering insights. The original hazard findings documentation and findings evaluation worksheets shall be an appendix to the final report. The report shall identify and describe those hazards that are the dominant risk contributors.

\subsection{PROCEDURE}

This procedure is divided into three major parts: (1) the facility hazard investigation; (2) the findings evaluation (performed in a team meeting format); and (3) an assessment of results.

The guidance in this procedure provides detailed steps of the risk evaluation process assuming the prerequisite actions listed below have already taken place.

- That team members with the appropriate expertise have been as sembled

- That logistic needs related to building entry such as building orientation, building escorts, and specialty resources and personnel needed by the investigators have been provided 
WHC-EP-0619

VOLUME 2

- That hazard identification checklists have been developed for each professional discipline involved in the walkdown investigation: structural analysis, electrical engineering, industrial safety, radiation safety, and environmental safety.

\subsubsection{Facility Hazard Investigation}

1. Conduct investigation walkdown for a subject facility. All team members will be provided access to one particular facility (or set of facilities) for an adequate number of days to complete the investigation. The investigator will walk through the facility and record findings on a checklist.

Note a: Documenting noncompliance with national codes or federal and state laws is not the focus of this investigation. The focus is only on facility conditions that represent a credible threat to human health and safety and potential releases to the environment.

Note b: A professional photographer will be supplied for a prearranged time during the scheduled walkdown.

Note c: Availability of required specialty personnel such as craft workers must be initiated by the investigator with assistance from the Program Manager.

2. Document findings from the scheduled walkdown investigations in a method particular to each professional discipline but appropriate as a permanent record. These findings will be considered the raw data and may be included in the final report as appendices.

3. Fill out the Findings Report worksheet using the information recorded during walkdowns. Use this procedure for all applicable hazards identified in the Hazards Category List (see Appendix A). $A$ blank Findings Report worksheet and instructions for completion are provided in Appendix $A$. The information from these worksheets will be evaluated during the team meetings.

\subsubsection{Facility Hazard Risk Evaluation}

The following steps describe the evaluation process performed in a team meeting format:

1. Gather the team to evaluate the risk of findings for a retired facility or set of facilities. The Program Manager generally will schedule the time and place of these meetings within a few working days after the scheriled investigation. This method allows investigations and evaluations to occur on an ongoing basis until all facilities are completed.

2. Assess all findings related to the hazard 1ist in Appendix A that are documented in the Findings Reports (this assessment is described in steps 3 through 8 ). Note any new hazard categories that have been discovered and add these to the list. 
3. For each finding in a hazard category, identify as many representative potential accidents and contributing factors as possible with all team members contributing. Record the results on the Risk Evaluation Summary Sheets (see Appendix B). Use this procedure for all hazard categories.

Note a: There may be secondary effects to consider. For example, crumbling roof panels can promote the spread of asbestos fibers. The collapsing structure would be a "Struck By" hazard and the spread of asbestos would be a "Release of Asbestos Hazard."

Note b: The same hazard may be documented by more than one investigator. Risks from potential hazards should be documented only once.

4. Assign each potential accident associated with a hazard to a consequence category (consequence categories and corresponding technical bases are provided in Appendix C). Record on Risk Evaluation Summary Sheets.

5. Assign a likelihood index for each potential accident associated with a hazard. (Likelihood indexes and associated technical bases are provided in Appendix D.) Record the results on Risk Evaluation Summary Sheets.

Note: Information should be solicited and recorded concerning administrative controls, degree of building access, and other factors that may affect the likelihood of an accident.

6. Assign both an accident category and a likelihood index to the hazard being analyzed after individual accidents have been addressed. In many cases, this assignment will correspond to the evaluation made for the most serious (likelihood and consequence) accident identified for that hazard. In other cases, however, the likelihood index may be higher if there are dozens of accidents in the same accident category with the same likelihood index.

7. Iterate on steps 2, 3, and 4 by forecasting 5 to 10 years into the future. Determine the likelihood or consequence of a particular hazard changing in time. Record on Risk Evaluation Summary Sheets.

8. Solicit corrective and/or mitigative actions that could reduce the risk of the hazard findings. Record on Risk Evaluation Summary Sheets.

\subsubsection{Assessment of Results}

After the team members have produced risk evaluations on all hazard findings, the risk assessment specialist has the following responsibilities to process the results.

1. Assign all hazards identified to a Risk Matrix category. (The Risk Matrix and associated technical basis are provided in Appendix E). 
WHC-EP-0619

VOLUME 2

2. Create a summary of the Risk Matrix category that each hazard is assigned to for each individual facility.

3. Determine the risk index associated with each facility by summing the risk indices associated with the Risk Matrix category of each hazard. (Weighting factors for each Risk Matrix category are described in Appendix E).

4. Create a ranking of facilities determined by the risk index.

5. Provide descriptions of dominant risk contributors and other engineering insights.

6. Perform risk sensitivity analyses. Risk is estimated assuming current facility use, control, and activities remain constant. Therefore, risk that is sensitive to changes in these assumptions should be identified.

\subsection{REFERENCES}

Hughes, M. C., 1992, Westinghouse Hanford Company Integrated Action Plan for the Followup to the Fatality at 105-F Building, (external letter 9204633B R2 to J. D. Wagoner, U. S. Department of Energy, Richland Field Office, August 10, 1992), Westinghouse Hanford Company, Richland, Washington.

Solomon, K. A., and K. A. Alesch, 1989, "The Index of Harm: A Measure for Comparing Occupational Risk Across Industries, "Journal of Occupational Accidents, Vol. 11, pp. 19-35.

Wagoner, J. D., 1991, U.S. Department of Energy, Richland Field Office, (RL) Self-Assessment Policy and Requirements for the Hanford Site, Revision 0, (external letter 91063138 to Contractors, Richland, Washington: Hanford Environmental Health Foundation; Kaiser Engineers Hanford Company; Pacific Northwest Laboratory; and Westinghouse Hanford Company, December 17, 1991), U. S. Department of Energy, Richland Field Office, Richland, Washington.

WHC-CM-1-3, Management Requirements and Procedures, Westinghouse Hanford Company, Richland, Washington. 
WHC-EP-0619

VOLUME 2

\section{APPENDIX A}

FINDINGS REPORT

$$
A-i
$$


WHC-EP-0619

VOLUME 2

A-i i 
WHC-EP-0619

VOLUME 2

\section{FINDINGS REPORT INSTRUCTIONS}

\subsection{INTRODUCTION}

This appendix provides guidance and criteria for completing the Findings Report.

\subsection{SPECIFIC CRITERIA}

\subsection{HAZARD CATEGORY}

The hazard category should be identified from the following 1 ist. If a finding cannot be applied to a category in this list, then a new hazard category will be created.

- Falling (tripping, slipping, falling through, falling off)

- $\quad$ Struck by or striking

- Drowning or suffocation

- Electrical shock

- Exposure to radiation

- Exposure to asbestos

- Exposure to lead

- Exposure to mercury

- Exposure to miscellaneous chemicals

- Exposure to biological hazards (i.e., disease, bites)

- Temperature extremes

- Fire

- Explosion

- Release of radioactive material

- Release of asbestos

- Release of lead

- Release of mercury

- Release of oil and/or petroleum products 


\subsection{HAZARD LOCATION}

- Release of miscellaneous chemicals

Information should be specific enough so team members can readily identify the location of the hazard. At the minimum, both the building and the room must be identified. The identification should be specific with regard to identifying wall/floor/ceiling, north/south/east/west, or specific measurements.

\subsection{POTENTIAL ACCIDENTS}

Provide a description of the kinds of potential accident(s) that could be associated with the hazard.

\subsection{FACTORS}

Provide a discussion of existing conditions or features that affect the likelihood of the hazard to result in an accident (i.e., absence of a personnel barrier, poor lighting, limited personnel access, power box cover normally in place, hallway is the only access route in facility).

\subsection{RISK ASSESSMENT}

Assign a consequence, 1ikelihood, and risk category for the two time frames under consideration (now to five years and beyond five years).

\subsection{POTENTIAL MITIGATION/PREVENTION}

Provide a short discussion of possible preventive or mitigative features that would reduce the likelihood or severity of the accident $(s)$. This need only be done for hazards likely to pose risk problems such as contributors to the critical, serious, or moderate categories (i.e., remove containers of hazardous chemicals, allow no access without protective equipment, remove bird droppings). 


\section{FINDINGS REPORT}

FACILITY :

DATE :

INVESTIGATOR:

\section{HAZARD:}

LOCATION:

POTENTIAL ACCIDENT(S):

FACTORS:

RISK ASSESSMENT MATRIX:

\begin{tabular}{|c|c|c|c|}
\hline & $\begin{array}{l}\text { Consequence } \\
\text { Category }\end{array}$ & $\begin{array}{l}\text { Likel ihood } \\
\text { Category }\end{array}$ & $\begin{array}{l}\text { Risk } \\
\text { Category }\end{array}$ \\
\hline $\begin{array}{l}\text { Now to } \\
5 \text { years }\end{array}$ & & & \\
\hline $\begin{array}{l}\text { Beyond } \\
5 \text { years }\end{array}$ & & & \\
\hline
\end{tabular}

POTENTIAL MITIGATION/PREVENTION: 
WHC-EP-0619

VOLUME 2 
WHC-EP-0619

VOLUME 2

APPENDIX B

FIINDINGS EVALUATION WORKSHEET

$B-i$ 
WHC-EP-0619

VOLUME 2

$B-i i$ 


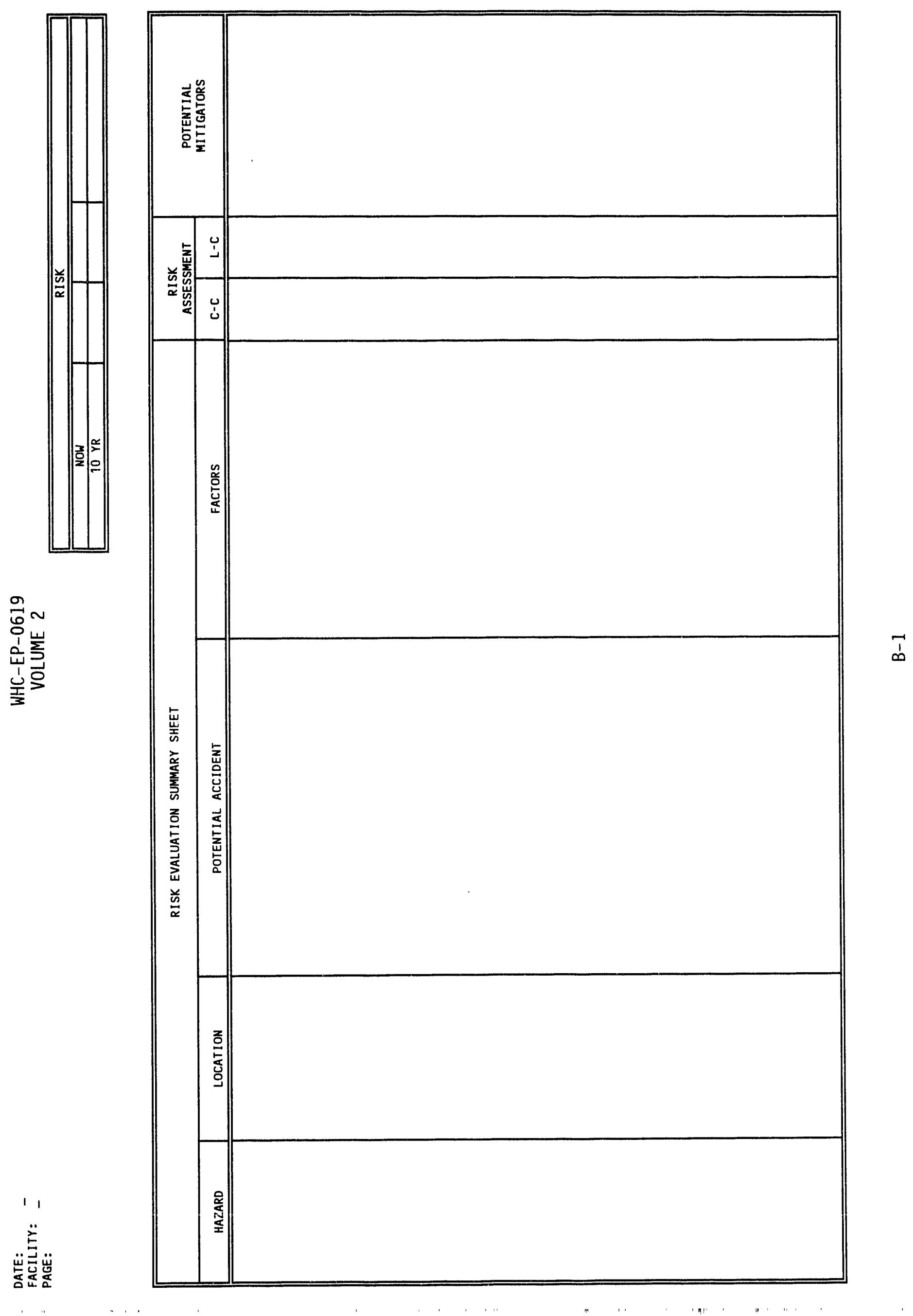


WHC-EP-0619

VOLUME 2

APPENDIX C

CONSEQUENCE CATEGORIES 
WHC-EP-0619

VOLUME 2

$$
c-i j
$$




\section{CONSEQUENCE CATEGORIES - DISCUSSION AND TECHNICAL BASES}

\subsection{INTRODUCTION}

This appendix provides a discussion of the consequence categories contained in Table $c-1$. This discussion includes the bases for the categories, definitions of their boundaries, and bases for the weighting factors.

Table $C-1$ is composed of four consequence categories. These categories are denoted as catastrophic, severe, unplanned releases, and minor (Roman numerals I, II, III, and IV.). This table connects the consequences with the receptors of concern: the public, Hanford Site personnel, or the environment. The weighting factors allow relative weighing of a findings consequences. From this, relative risks values can be developed and lists of items ranked by relative risk can be produced.

The consequence categories are designed to be grouping mechanisms into which accidents can be grouped based on outcome similarities. This creates a structure by which differing accident effects can be compared on a normalized basis. The weighting factors associated with the consequence categories are the normalizing tool and express the societal attitudes concerning the effects of an accident. These weighting factors are developed by observing risk avoidance behavior in a population and then assigning numerical relationships. No absolute risk significance should be applied to these values.

\subsection{CATEGORY DESCRIPTION}

\subsection{CATEGORY I - CATASTROPHIC}

Catastrophic is the highest consequence category with which this procedure is concerned. This category addresses any hazards that can produce accidents that can cause death and includes exposure to radioactive materials or toxic chemicals.

\subsection{CATEGORY II - SEVERE}

This category encompasses hazards in which accident consequences would produce severe injury, significant lost work time, or long-term disability. The use of the term acute in the description of this category implies promptness as well as severity. Therefore, in the case of radioactive or toxic material exposure, the effect must be severe and occur in a relatively short time after exposure. Other accidents such as falling, having the roof cave in, or contacting an energized circuit have a consequence character that can be termed prompt as well as severe. For example, radiation doses on the order of 200 rem result in severe debilitating effects that would be considered prompt (acute) as well as severe. Similarly, contact with toxic chemicals such as acids, bases, and toxic gasses that produce severe injury would be considered to have prompt effects. As was the case in Category I, no differentiation is intended between the public and personnel.

$$
\text { C-1 }
$$


WHC-EP-0619

VOLUME 2

\subsection{CATEGORY III - UNPLANNED RELEASE}

Unplanned release encompasses events involving releases of radioactive or toxic materials to the environment. This category, for the purposes of reporting, is further divided into three groups: (1) releases resulting in significant amounts of the environment being contaminated; (2) releases resulting in small amounts of the environment being contaminated; and (3) releases that may or may not exceed regulatory allowables, but which would affect insignificant amounts of the environment.

\subsection{CATEGORY IV - MINOR}

Minor encompasses the accidents that result in minor injury. This category includes effects from biological hazards such as animal and insect bites or stings, or disease from contact with bird or bat droppings. Also included are minor occupational type injuries such as scrapes, bruises, cuts, and strains.

\subsection{CATEGORY BASIS}

The consequence categories described in this appendix were selected based on the concepts contained in the WHC PPG. The use of consequence categories is an accepted part of the qualitative risk assessment process.

The specific categories were selected based on the scope of this risk evaluation. The need for specifically identifying the potential effects of hazards on public and personnel safety and the possibility of environmental insult were prime considerations in the category choices. The choice of four categories is a result of balancing the need to differentiate between potential effects while keeping the evaluation process manageable in terms of complexity, budget, and schedule constraints. The difference between this evaluation and the PPG is mainly in the level of detail presented in the PPG.

For Category I, the specific concern is fatalities. Societally, the concern about accidents causing death is significantly greater than those causing severe injury or long term disability. Therefore, it is appropriate to assign the most severe consequence group to hazards that have the potential to cause accidental death.

No differentiation is made between personnel and the uninvolved public. Although this is at variance with the WHC PPG, it is appropriate for this evaluation. The PPG was meant to be used on operating facilities that provide a societal benefit. In the case of operating facilities, it is logical to differentiate between the public and personnel as far as risk acceptance or risk avoidance is concerned. The societal value placed on a product being produced necessitates the acceptance of some level of personnel risk of death, however low that level may actually be.

The ability to attract and maintain a work force to produce the product is the determining factor for the acceptable level of risk of death. However, when a facility represents no societal benefit, a differentiation between the public and personnel as far as death risk is concerned is much harder to 
justify. Such a case can be made for the storage and disposal of very toxic materials such as nerve gas. This material represents a significant hazard to both the personnel and the public. The desire by the public for risk aversion is correspondingly high. The safe storage and disposal of such materials, however, necessitates the personnel to accept some greater level of death risk than would be tolerated by the general public so that the general public would be protected. Therefore, such a case would warrant splitting public and personnel consequences into different categories. Because the retired facilities do not represent this type of hazard, no differentiation is made between personnel and the public in the case of death or severe injury.

For Category II, the specific concern is a situation that has the potential to cause severe injury or long-term disability. This category has significant societal concern, but the concern is low enough to warrant separating it from the concern considered in Category I.

Category III represents a departure from the general consequence concepts used in Categories I and II. The difference lies in the fact that Category III is not a personnel safety category. Prompt personnel or public harm from a release is to be counted in Categories I and II. The environmental aspect of the release is counted in Category III.

Category III-1 are releases resulting in significant amounts of the environment being contaminated. Category III-2 are releases resulting in small amounts of the environment being contaminated. Category III-3 are releases that may or may not exceed regulatory allowables, but affect insignificant amounts of the environment.

If a release could require extensive remediation effort or is of a magnitude likely to also cause health effects (risks to humans are accounted for in Categories I, II, or IV) then the classification should be III-1. If the release would require no remediation or affects insignificant portions of the environment, then the classification should be III-3. Releases that are important but would require only simple remediation should be classified as III-2. Hazardous material that is contained and controlled within the facility will be designated as Category III-3.

No attempt to assign a specific environmental harm is made for Category III-3, but the divisions within the category allow recognition that environmental releases do represent costs. On a relative scale, this study assumes that less societal concern exists for events of this nature than for events that fit in Categories I and II.

Category IV is the miscellaneous category for the consequences that have not met the severity to be classed as I, II, or III. This category is provided to ensure that low consequence hazards are not overlooked. Large numbers of minor hazards can be an indicator that accidents with significant consequence may be a problem in analysis projections into the future.

\subsection{CONSEQUENCE WEIGHTING FACTORS}

The consequence weighting factors were derived from the relative risk values contained in the PPG. Those factors were developed specifically for 
WHC-EP-0619

VOLUME 2

the PPG and reflect studies that attempt to quantify the differences in societal concern among various consequence categories. The factors are normalized to one for the most severe category. Lesser consequences are assigned fractional values of one. Although the difference between the category weighting factors is important, the absolute accuracy of a qualitative risk evaluation is not sufficient to achieve values with better than one half order of magnitude accuracy. However, for the purposes of identifying dominant risk contributors and comparing alternative courses of action, the accuracy is more than sufficient.

The groups in Category III are assigned modifying values to be multiplied with the category weighting factor. Groups 1,2 and 3 have modifying values of $1.0,0.1$, and 0.01 , respectively. These modifying values account for the reduced potential environmental effects expected from events assigned to groups 2 and 3 as compared to group 1 . In effect, a group 2 event in Category III is given about the same weight as an event assigned to Category IV. Group 3 events have even less weight. By having the Category III divisions rather than assigning releases explicitly to Category IV keeps the environmental issues conveniently separated to allow better recognition of their risk contribution. 
WHC-EP-0619

VOLUME 2

Table C-1. Consequence Categories.

\begin{tabular}{|c|c|c|c|c|}
\hline \multirow[t]{2}{*}{ Effect on } & $\frac{I}{\text { Catastrophic }}$ & $\begin{array}{c}\text { II } \\
\text { Severe }\end{array}$ & $\begin{array}{l}\text { III } \\
\text { Unplanned } \\
\text { release }\end{array}$ & $\begin{array}{c}\text { IV } \\
\text { Minor }\end{array}$ \\
\hline & $\begin{array}{l}\text { Loss of life } \\
\text { (personnel or } \\
\text { public) } \\
\text { (including } \\
\text { fatality from } \\
\text { radiological, } \\
\text { chemicals, or } \\
\text { biological } \\
\text { exposures) }\end{array}$ & $\begin{array}{c}\text { Severe injury } \\
\text { (personnel } \\
\text { disability or } \\
\text { significant lost } \\
\text { time accident) } \\
\text { (including severe } \\
\text { injury from } \\
\text { radiological, } \\
\text { chemical, or } \\
\text { biological } \\
\text { exposure) }\end{array}$ & $\begin{array}{l}\text { Unplanned } \\
\text { release of } \\
\text { radioactive, } \\
\text { chemical, or } \\
\text { hazardous } \\
\text { material } \\
\text { to the } \\
\text { environment }\end{array}$ & $\begin{array}{c}\text { Minor onsite } \\
\text { injury }\end{array}$ \\
\hline $\begin{array}{c}\text { Public } \\
\text { or } \\
\text { personnel }\end{array}$ & -- & -- & $N / A$ & -- \\
\hline Environment & $N / A$ & $N / A$ & $\begin{array}{l}\text { III-1 }=1.0 \\
\text { III-2 }=0.1 \\
\text { III-3 }=0.01\end{array}$ & $N / A$ \\
\hline $\begin{array}{c}\text { Consequence } \\
\text { weighting } \\
\text { factors }\end{array}$ & 1.0 & 0.1 & 0.03 & 0.003 \\
\hline
\end{tabular}

N/A $=$ not applicable. 
WHC-EP-0619

VOLUME 2

APPENDIX D

LIKELIHOOD INDEX

$D-i$ 
WHC-EP-0619

VOLUME 2

$D-i j$ 


\subsection{LIKELIHOOD INDEX}

A likelihood index is estimated for each event examined in the qualitative risk evaluation process. An event, for this procedure, involves an identified hazard and causes harm to a person or an environmental release. In the findings, evaluation process consequence categories are identified before the likelihood is estimated.

The intent in using the likelihood categories is to simplify the likelihood assessment and to encourage consistency in estimating likelihoods. The likelihood indices to be used in this study are shown in Table D-1. These indices were taken from MIL-STD-88:B, System Safety Program Requirements. The numerical values assigned to these indices were taken from Table A-2 "Priority Planning Grid A.pplication Probabi1ity' Table" of WHC-CM-1-3, MRP 5.1.

Specific and generic data will be used to establish benchmarks. For example, because a fall through a roof panel has occurred, then the likelihood of a similar event involving a roof panel must be at least 1.0 . If rigid administrative controls must be bypassed to result in an event, then human reliability screening values such as $1 \mathrm{E}-2$ can be used to estimate a likelihood. This kind of guidance will be provided by tr.a risk specialist during the evaluation process.

Table D-1 Likelihood Index.

\begin{tabular}{|l|c|l|c|}
\hline \multicolumn{1}{|c|}{ Level } & Index & \multicolumn{1}{|c|}{ Description } & Likelihood \\
\hline Frequent & A & Likely to occur frequently & 1.0 \\
\hline Probable & B & $\begin{array}{l}\text { Likely to occur several times in } \\
\text { the life of an item }\end{array}$ & $1 \mathrm{E}-1$ \\
\hline Occasional & C & $\begin{array}{l}\text { Likely to occur sometime in the } \\
\text { life of an item }\end{array}$ & $1 \mathrm{E}-2$ \\
\hline Remote & D & $\begin{array}{l}\text { Unlikely but possible to occur in } \\
\text { life of an item }\end{array}$ & $1 \mathrm{E}-4$ \\
\hline Improbable & E & $\begin{array}{l}\text { So unlikely that it can be assumed } \\
\text { occurrence will not be experienced }\end{array}$ & IE-6 \\
\hline
\end{tabular}

\subsection{REFERENCES}

MIL-STD-882B, System Safety Program Requirements, as amended.

WHC-CM-1-3, Management Requirements and Procedures, Westinghouse Hanford Company, Richland, Washington. 
WHC-EP-0619

VOLUME 2

\section{APPENDIX E}

RISK MATRIX 
WHC-EP-0619

VOLUME 2

$E-i i$ 


\subsection{RISK MATRIX}

Risk is a function of likelihood and consequence; the risk matrix is a table used to assign risk categories. The consequence and likelihood for findings are used to determine the risk category. The table is a visual presentation of the numerical ranges defining risk for the product of the likelihood index value and the Consequence Category weighting factor. The categories and associated numbers were derived from the WHC PPG. The intent in using the risk categories is to simplify the risk determination and encourage consistency in presenting risk. The table also is a convenient method for establishing groups to aid in presentation of the evaluation results.

The following numerical ranges define the risk categories:

$\begin{array}{lll}\text { - } & \text { Critical } & -0.1 \text { to } 1.0 \\ \text { - } & \text { Merious } & 1 \mathrm{E}-2 \text { to } 0.1 \\ \text { - } & \text { Minorate } & -1 \mathrm{E}-3 \text { to } 1 \mathrm{E}-2 \\ \text { - Negligible }-1 \mathrm{E}-5 \text { to } 1 \mathrm{E}-3 \\ \end{array}$

Although the numerical ranges by themselves have no absolute meaning, the assignment of categories does imply a degree of risk acceptability or unacceptability. Numbers of similar magnitude are grouped to make a range that defines a risk category. The risk matrix is not symmetrical because the consequence weighting factors do not increase uniformly per category.

Items that fall in the critical risk category would be considered unacceptable, requiring immediate attention to reduce either the severity or likelihood. Items in the serious category would also be considered unacceptable from a risk point of view unless other extenuating circumstances existed, and would aiso require immediate attention. Items in the moderate, minor, and negligible categories generally are considered to have acceptable risk. Items in the high end of the moderate category may require closer evaluation to ensure that no excessive risk exists. 
WHC-EP-0619

VOLUME 2

Table E-1. Risk Matrix Categories.

\begin{tabular}{|c|c|c|c|c|}
\hline $\begin{array}{l}\text { Likel ihood } \\
\text { index }\end{array}$ & $\begin{array}{c}\text { Consequence } \\
\text { category } \\
\text { I } \\
\end{array}$ & $\begin{array}{c}\text { Consequence } \\
\text { category } \\
\text { II } \\
\end{array}$ & $\begin{array}{c}\text { Consequence } \\
\text { category } \\
\text { III } \\
\end{array}$ & $\begin{array}{c}\text { Consequence } \\
\text { category } \\
\text { IV } \\
\end{array}$ \\
\hline A & Critical & Critical & $\begin{array}{ll}1 & \text { Serious } \\
2 & \text { Moderate } \\
3 & \text { Minor }\end{array}$ & Moderate \\
\hline B & Critical & Serious & $\begin{array}{ll}1 & \text { Moderate } \\
2 & \text { Minor } \\
3 & \text { Negligible }\end{array}$ & Minor \\
\hline C & Serious & Moderate & $\begin{array}{ll}1 & \text { Minor } \\
2 & \text { Negligible } \\
3 & \text { Negligible }\end{array}$ & Minor \\
\hline D & Minor & Minor & $\begin{array}{ll}1 & \text { Negligible } \\
2 & \text { Negligible } \\
3 & \text { Negligible }\end{array}$ & Negligible \\
\hline $\mathbf{E}$ & Negligible & Negligible & $\begin{array}{ll}1 & \text { Negligible } \\
2 & \text { Negligible } \\
3 & \text { Negligible }\end{array}$ & Negligible \\
\hline
\end{tabular}




\section{DISTRIBUTION}

\section{Number of Copies}

\section{ONSITE}

3

U. S. Department of Energy Richland Field office

J. K. Erickson

A. C. Harris

A5-19

DOE-RL Public Reading Room

A5- 19

Kaiser Engineers Hanford

1 M. S. Ruben

E6-31

2 Pacific Northwest Laboratory

G. J. Vargo

K3-56

PNL Technical Files

$\mathrm{K} 1-11$

Westinghouse Hanford Company

W. J. Adam

E. L. Ahola

H4-67

G. A. Coles

L4-90

C. L. Cooley

HO-31

R. G. Egge

R3-54

J. E. Hodgson

$\mathrm{R} 2-77$

T. F. Johnson

X7-02

D. G. Kachele

$x 0-21$

N. R. Kerr

S4-67

H. E. Marquez

H4-67

R. E. Merriman

H4-67

C. M. Monasmith

L4-90

M. R. Morton

L4-90

J. F. Renken

$E$. Senger

R2-77

X7-02

J. B. Shannon

R2-77

T3-11

M. V. Shultz

HO-31

S. R. Staley

R3-54

W. E. Taylor

M. A. Tredway

B. F. Weaver

H4-67

R. A. Winship

R3-54

T3-11

A3-30

J. J. Zimmer Central Files (2)

H4 $4-67$

L8-04

Docket Files

H5-36

Distr-1 
WHC-EP-0619

VOLUME 2

Environmental Data

Management Center (2)

Environmental Restoration

Safety Support Files (3)

H6-08

Information Release

H4-67

Administration (3)

H4-17 

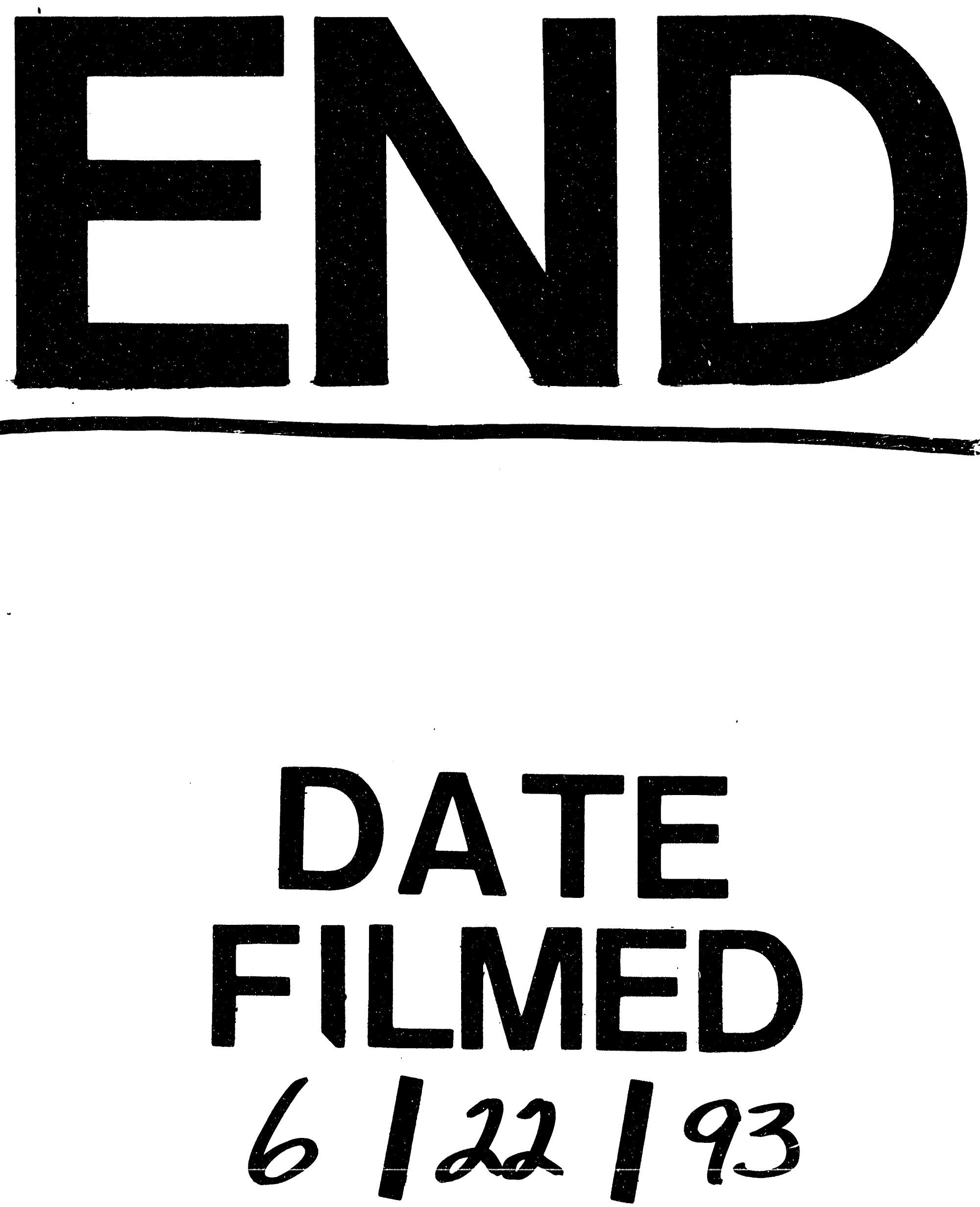
